\title{
Daphniphyllum Alkaloids: Recent Findings on Chemistry and Pharmacology
}

\author{
Authors \\ Haifeng $\mathbf{W u}^{1}$, Xiaopo Zhang ${ }^{1}$, Lisheng Ding ${ }^{2}$, Shilin Chen ${ }^{1,3}$, Junshan Yang ${ }^{1}$, Xudong $\mathrm{Xu}^{1}$ \\ Affiliations \\ ${ }^{1}$ Institute of Medicinal Plant Development, Chinese Academy of Medical Sciences and Peking Union Medical College, \\ Beijing, China \\ ${ }^{2}$ Chengdu Institute of Biology, Chinese Academy of Sciences, Chengdu, China \\ ${ }^{3}$ Institute of Chinese Materia Medica, China Academy of Chinese Medical Sciences, Beijing, China
}

Key words

- Daphniphyllum

- Daphniphyllaceae

- alkaloids

- synthesis

- biological activity

\section{Abstract}

\section{$\nabla$}

The unique polycyclic fused ring systems of Daphniphyllum alkaloids, along with their extensive bioactivities, make this family of alkaloids especially attractive targets for total synthesis and biogenetic studies. Successive discoveries of new alkaloids with unprecedented skeletons have made a great contribution to structural diversities of alkaloids elaborated by plants of the genus Daphniphyllum. By the end of 2008, more than 200 alkaloids belonging to 14 different skeletal types have been isolated from different parts of plants of thirteen Daphniphyllum species. These alkaloids show cytotoxic, antioxidant, vasorelaxant, and antiplatelet activating factor effects. The plausible biosynthetic pathways for Daphniphyllum alkaloids have been proposed and biomimetic total syntheses of some alkaloids completed. To provide an update of the previous reviews published in 2009, new structures, synthesis, and bioactivity of Daphniphyllum alkaloids reported in recent years are presented in this article. In the meantime, an additional 54 novel alkaloids have been isolated and identified. Among them, some possess unprecedented frameworks. Several inspired organic syntheses were completed.

\section{received April 7, 2013 \\ revised June 22, 2013 \\ accepted Sept. 16, 2013}

\section{Bibliography}

Dol http://dx.doi.org/

10.1055/s-0033-1351024

Published online November 8 ,

2013

Planta Med 2013; 79 :

1589-1598 @ Georg Thieme

Verlag KG Stuttgart - New York .

ISSN 0032-0943

\section{Correspondence \\ Prof. Xudong Xu}

Institute of Medicinal Plant

Development

Chinese Academy of Medical

Sciences and Peking Union

Medical College

No. 151, Malianwa North Road

Haidian District, Beijing 100193

China

Phone: + 861057833296

Fax: +861057833296

xdxu@implad.ac.cn

\section{Introduction}

\section{$\nabla$}

Daphniphyllum alkaloids, triterpenoid alkaloids with highly variable polycyclic skeletons, are characteristic constituents of the genus Daphniphyllum. Daphniphyllum, referring to Daphne and leaf in Greek, is the sole genus in the Daphniphyllaceae family, including about 30 species of dioecious evergreen trees and shrubs mainly distributed from India to Japan and from central China to New Guinea [1]. About ten species were found in China, some of which are traditionally used in the treatment of asthma, rheumatism, and snakebites. The isolation of the first C30-type Daphniphyllum alkaloid, daphnimacrine from D. macropodum, was reported by Yagi in 1909 [2]; however, the structure remained unresolved. The systematic investigation of Daphniphyllum alkaloids began in the $1960 \mathrm{~s}$. Three new alkaloids, daphnicaline, daphnicadine, and daphnicamine, were isolated from the seeds of $D$. calycinum, Niu-ErFon (in Chinese) by Fang et al. [3]. Niu-Er-Fon is a poisonous plant growing in southern China. Its seed oils are only used as biodiesel because of toxicity. The authors measured the melting points and proposed the molecular formulae of these al- kaloids. Subsequently, an investigation of the Hong Kong species of $D$. calycinum and D. glaucescens resulted in the isolation of another three new alkaloids, calycine, glaucescine, and glaucescinine [4]. The ${ }^{1} \mathrm{H}-\mathrm{NMR}$ spectrum of calycine was reported. In 1966, the structures of several alkaloids from $D$. macropodum were determined with X-ray analysis of their hydrobromide by Hirata et al. [57]. Since then, more than 200 Daphniphyllum alkaloids have been isolated from the genus Daphniphyllum until the end of 2008. The initial five skeletal types have been expanded to 14 main types. These alkaloids show cytotoxic, antioxidant, vasorelaxant, and antiplatelet activating factor (PAF) effects. The unusual ring systems of Daphniphyllum alkaloids, together with their biological aspects, make this family of alkaloids especially attractive targets for total synthesis and biogenetic studies. In 1986, the first total synthesis of a Daphniphyllum alkaloid, (+)-methyl homodaphniphyllate, was completed by Heathcock et al. [8]. Subsequently, a series of total syntheses were reported [9-11]. A biosynthetic pathway for Daphniphyllum alkaloids was also proposed and several biomimetic total syntheses of some Daphniphyllum alkaloids were conducted by Heathcock 


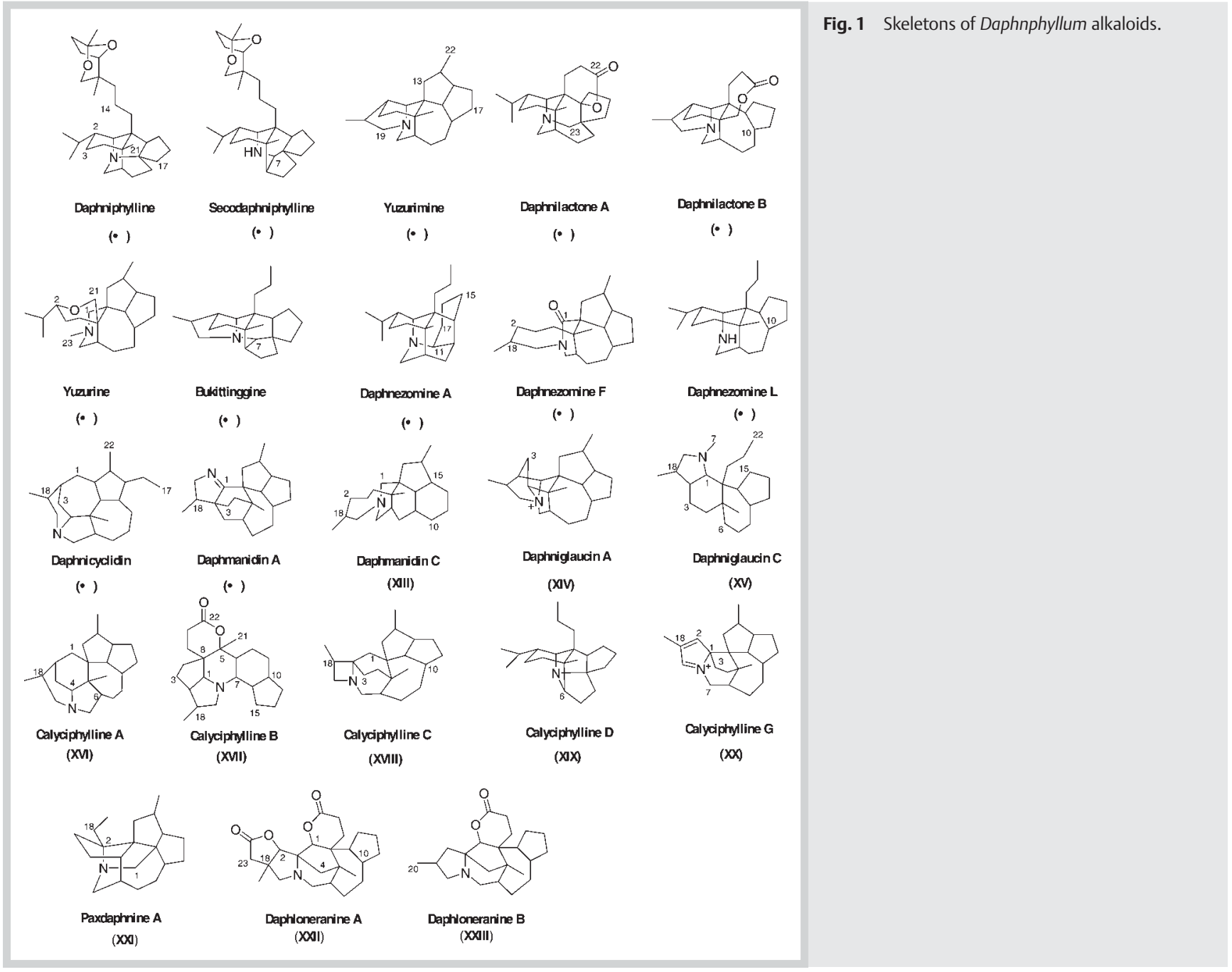

and coworkers [12-18]. Considering structural peculiarities of Daphniphyllum alkaloids, Yamamura et al. successively reviewed the isolation, structural elucidation, and chemical and biological properties of Daphniphyllum alkaloids in 1975 and 1986 [19,20]. Thereafter, the application of modern chromatographic and spectroscopic techniques greatly facilitated the further discoveries of Daphniphyllum alkaloids. In 2003, Kobayashi and Morita summarized reports published during the 15-year period between 1987 and 2002 [21]. From then on, 66 new alkaloids from 11 species of Daphniphyllum had been reported until 2007, and about two-thirds of these alkaloids were isolated from the Chinese species of Daphniphyllum by Chinese researchers. Li and Guo published a mini-review highlighting progress over that period [22]. In 2009, the two comprehensive reviews were published, respectively $[23,24]$. Both thoroughly summarized chemical structures, biological activities, biosynthesis, and organic synthesis of all reported Daphniphyllum alkaloids. Since then, an additional 54 novel alkaloids have been isolated from nine species of the Daphniphyllum genus. Some of these alkaloids belong to the known skeleton, while others possess unprecedented frameworks. In addition, several elegant organic syntheses were also completed. To provide an update of the previous reviews, this article focuses on new structures, synthesis, and biological activities of Daphniphyllum alkaloids reported in the past few years (2009-present).

\section{Phytochemistry}

\section{$\nabla$}

Daphniphyllum alkaloids possess complex polycyclic ring systems represented by a fused pentacyclic, hexacyclic, heptacyclic, or octacyclic skeleton or an aza-adamantane nucleus. Most of these alkaloids were derived from six molecules of the mevalonic acid pathway via a squalene-like intermediate except for a few that originated from amino acids. According to the structural classification proposed by Kobayashi, Daphniphyllum alkaloids are divided into 14 main structural types including daphniphyllines, secodaphniphyllines, yuzurimines, daphnilactone A, daphnilactone $\mathrm{B}$, yuzurines, bukittinggines, daphnezomines, daphnicyclidins, daphmanidins, daphniglaucins, calyciphyllines, paxdaphnines, and daphlongeranines $\mathrm{A}$ and $\mathrm{B}$, as shown in 0 Fig. 1. The classification of recently isolated alkaloids basically follows that of previous reviews, but the newly obtained skeletons have been added ( Table 1 ).

\section{Daphniphylline}

Daphniphylline-type alkaloids possess 22 carbon cores with or without the $\mathrm{C} 8$ side chain. The $\mathrm{C} 8$ unit consists of 6-oxabicyclo [3.2.1] octane or 2,8-dioxabicyclo[3.2.1]octane. Three novel daphniphylline-type alkaloids, 11-hydroxycodaphniphylline (1) [25], daphnezomine V (2) [26], and homodaphniphyllate (3) lacking 
Table 1 Daphniphyllum alkaloids reported in recent years.

\begin{tabular}{|c|c|c|c|c|}
\hline No. & Compounds & Sources & Parts & Ref. \\
\hline 1 & 11-Hydroxycodaphniphylline & D. subverticillatum Merr. & leaves & [25] \\
\hline 2 & Daphnezomine V & D. humile Maxim. ex Franch. & leaves and branches & [26] \\
\hline 3 & Homodaphniphyllate & D. calycinum Benth. & stems and leaves & [27] \\
\hline 4 & Calycinumine $\mathrm{A}$ & D. calycinum Benth. & twigs & [28] \\
\hline 5 & 9,10-Epoxycalycinine A & D. calycinum Benth. & stems and leaves & [27] \\
\hline 6 & Macropodumine J & D. macropodum Miq. & bark & [29] \\
\hline 7 & Macropodumine K & D. macropodum Miq. & bark & [29] \\
\hline 8 & 4,21-Deacetyl-deoxyyuzurimine & D. macropodum Miq. & bark & [30] \\
\hline 9 & Daphnezomine T & D. humile Maxim. ex Franch. & leaves and branches & [26] \\
\hline 10 & Daphhimalenine B & D. himalense (Benth.) Muell.-Arg & leaves & [31] \\
\hline 11 & Daphangustifoline B & D. angustifolium Hutch. & whole plants & [32] \\
\hline 12 & Daphhimalenine C & D. himalense (Benth.) Muell.-Arg & leaves & [33] \\
\hline 13 & 17-Hydroxydaphnigraciline & D. subverticillatum Merr. & leaves & [25] \\
\hline 14 & Daphlongamine I & D. longeracemosum Rosenth. & fruits & [34] \\
\hline 15 & Daphlongamine J & D. longeracemosum Rosenth. & fruits & [34] \\
\hline 16 & Daphlongeranine $\mathrm{F}$ & D. longeracemosum Rosenth. & fruits & [35] \\
\hline 17 & Daphlongeranine D & D. longeracemosum Rosenth. & fruits & [36] \\
\hline 18 & Daphlongeranine $\mathrm{E}$ & D. longeracemosum Rosenth. & fruits & [36] \\
\hline 19 & Daphmalenine A & D. himalense (Benth.) Muell.-Arg & leaves & [37] \\
\hline 20 & Daphmalenine B & D. himalense (Benth.) Muell.-Arg & leaves & [37] \\
\hline 21 & Daphnioldhamine A & D. oldhami (Hemsl.) Rosenth. & fruits & [38] \\
\hline 22 & Daphmacromine A & D. macropodum Miq. & leaves and stems & [39] \\
\hline 23 & Daphmacromine B & D. macropodum Miq. & leaves and stems & [39] \\
\hline 24 & Daphmacromine C & D. macropodum Miq. & leaves and stems & [39] \\
\hline 25 & Daphmacromine D & D. macropodum Miq. & leaves and stems & [39] \\
\hline 26 & Daphmacromine E & D. macropodum Miq. & leaves and stems & [39] \\
\hline 27 & Daphmacromine F & D. macropodum Miq. & leaves and stems & [39] \\
\hline 28 & Daphmacromine G & D. macropodum Miq. & leaves and stems & [39] \\
\hline 29 & Daphmacromine H & D. macropodum Miq. & leaves and stems & [39] \\
\hline 30 & Daphmacromine I & D. macropodum Miq. & leaves and stems & [39] \\
\hline 31 & Daphmacromine J & D. macropodum Miq. & leaves and stems & [39] \\
\hline 32 & Dapholdhamine A & D. oldhami (Hemsl.) Rosenth. & leaves & [40] \\
\hline 33 & Angustimine & D. angustifolium Hutch. & twigs & [41] \\
\hline 34 & Dapholdhamine B & D. oldhami (Hemsl.) Rosenth. & leaves & [40] \\
\hline 35 & Daphnezomine U & D. humile Maxim. ex Franch. & leaves and branches & [26] \\
\hline 36 & Daphlongeranine C & D. longeracemosum Rosenth. & fruits & [36] \\
\hline 37 & Daphnezomine L methyl ester & D. subverticillatum Merr. & leaves & [25] \\
\hline 38 & Calycinumine B & D. calycinum Benth. & twigs & [28] \\
\hline 39 & Dapholdhamine C & D. oldhami (Hemsl.) Rosenth. & leaves & [40] \\
\hline 40 & Dapholdhamine D & D. oldhami (Hemsl.) Rosenth. & leaves & [40] \\
\hline 41 & Caldaphnidine $\mathrm{H}$ & D. calycinum Benth. & leaves and stems & [42] \\
\hline 42 & Angustifolimine & D. angustifolium Hutch. & twigs & [41] \\
\hline 43 & Paxiphylline C & D. paxianum Rosenth. & twigs and leaves & [43] \\
\hline 44 & Daphangustifoline A & D. angustifolium Hutch. & whole plants & [32] \\
\hline 45 & Subdaphnidine A & D. subverticillatum Merr. & leaves & [25] \\
\hline 46 & Daphlongamine $\mathrm{E}$ & D. longeracemosum Rosenth. & leaves & [45] \\
\hline 47 & Daphlongamine F & D. longeracemosum Rosenth. & leaves & [45] \\
\hline 48 & Daphlongamine G & D. longeracemosum Rosenth. & leaves & [45] \\
\hline 49 & Daphhimalenine D & D. himalense (Benth.) Muell.-Arg & leaves & [33] \\
\hline 50 & Paxiphylline D & D. paxianum Rosenth. & twigs and leaves & [43] \\
\hline 51 & Paxiphylline E & D. paxianum Rosenth. & twigs and leaves & [43] \\
\hline 52 & Daphlongamine H & D. longeracemosum Rosenth. & leaves & [45] \\
\hline 53 & Daphhimalenine A & D. himalense (Benth.) Muell.-Arg & leaves & [31] \\
\hline 54 & Daphenylline & D. longeracemosum Rosenth. & fruits & [46] \\
\hline
\end{tabular}

the C8 unit [27], were recently isolated ( Fig. 2). Daphnezomines $\mathrm{V}(\mathbf{2})$ was an $\mathrm{N}$-oxide form of daphnilongeranin $\mathrm{D}$.

\section{Yuzurimine}

Yuzurimine-type alkaloids contain 22 carbon atoms commonly with a C-9-C-10 double bond, and C-22 is mostly a methyl ester of a carboxyl group. Recently, nine new yuzurimine-type alkaloids, calycinumine A (4) [28], 9,10-epoxycalycinine A (5) [27], macropodumines J (6) and K (7) [29], 4,21-deacetyl-deoxyyuzurimine (8) [30], daphnezomine T (9) [26], daphhimalenine B (10) [31], daphangustifoline B (11) [32], and daphhimalenine C (12) [33] have been reported ( Fig. 2). Calycinumine A (4) is the first example of a C-22-nor yuzurimine-type alkaloid and its structure was confirmed by a single-crystal X-ray diffraction. Macropodumine $\mathrm{J}(\mathbf{6})$ contains a nitrile group, which is relatively rare in naturally occurring alkaloids. Daphnezomine T (9) is the first al- 


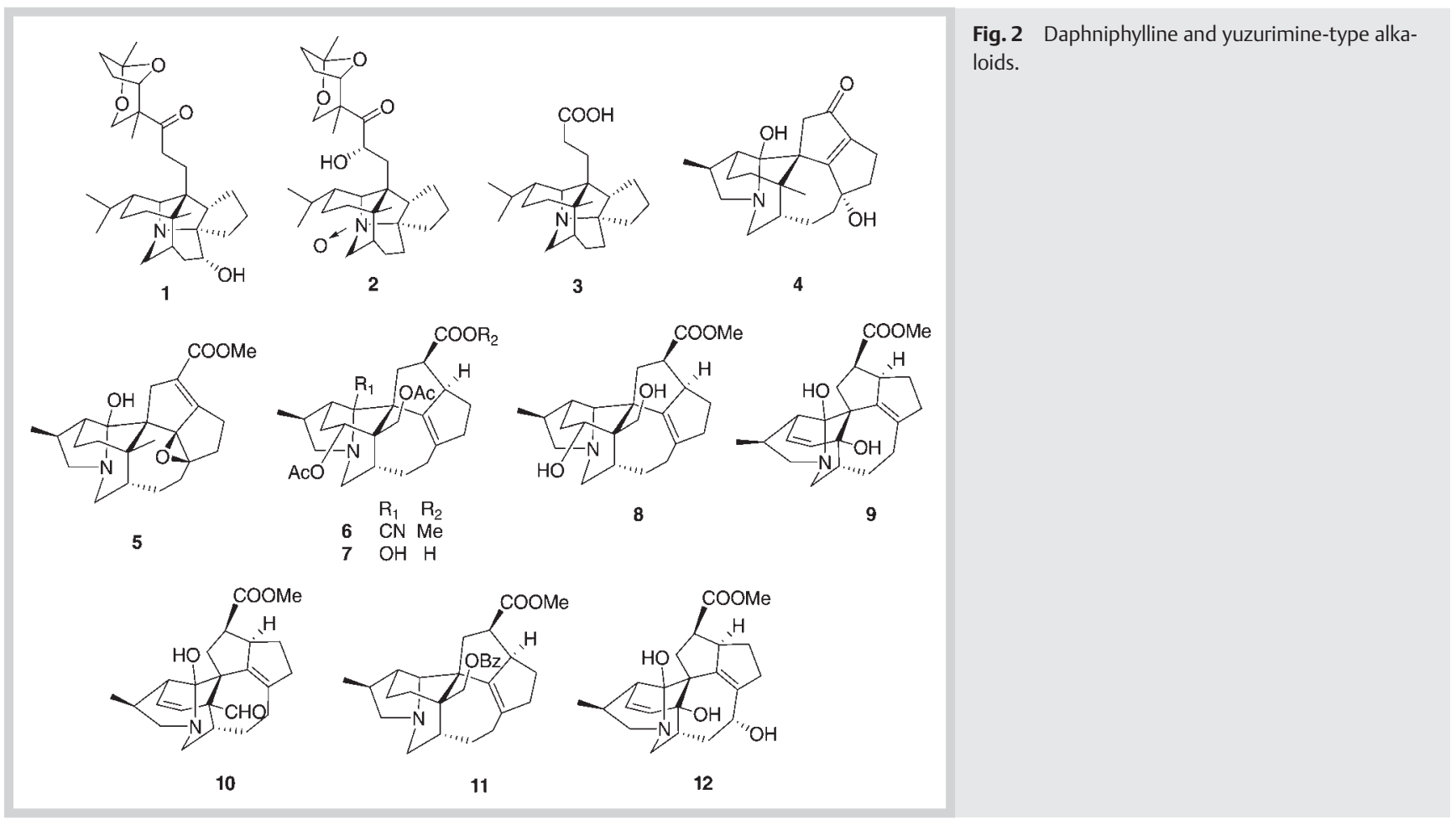

kaloid without a branched $\mathrm{C}_{1}$ unit at C-5. Daphangustifoline B (11) is the first alkaloid with a benzyl group in the genus of Daphniphyllum. Biogenetically, daphnezomine T (9) might be generated from an intermediate-like pordamacrine $B$, which could be derived from yuzurimine by the elimination of acetic acid from C-3-C-4 and hydrolysis of acetyl ester at C-21, via the oxidative loss of the $\mathrm{C} 1$ branch at $\mathrm{C}-5$. Daphhimalenine $\mathrm{B}(\mathbf{1 0})$ might undergo oxidation to give intermediate $\mathrm{A}$, and then oxidative decarboxylation of the aforementioned intermediate and subsequent oxidation might yield daphnezomine T (9) (๑ Fig. 3).

\section{Yuzurine}

Different from other Daphniphyllum alkaloids with 22 C-atoms, yuzurine-type alkaloids have 23 carbons in their frameworks with a methyl group attached to the nitrogen atom. In the last few years, nineteen yuzurine-type alkaloids, 17-hydroxydaphnigraciline (13) [25], daphlongamines I (14) and J (15) [34], daphlongeranine $\mathrm{F}$ (16) [35], daphlongeranines D (17) and E (18) [36], daphmalenines A (19) and B (20) [37], daphnioldhamine A (21) [38], and daphmacromines A-J (22-31) [39], have been obtained ( Fig. 4). Daphmalenines A (19) and B (20) are biogenetically related yuzurine-type Daphniphyllum alkaloids of the rare $(14 R, 15 S)$ series, possessing an unusual penta- or tetracyclic ring system, respectively. Daphmalenine B (20) is the first seco-10,17yuzurine-type Daphniphyllum alkaloid. The absolute configurations of daphmalenines A (19) and B (20) were determined on $\mathrm{X}$-ray diffraction by using the Flack parameter and computational methods, respectively. Daphmalenines A (19) and B (20) could be originated from the common imine intermediate, which involves an alternative route during the process of the formation of the C-14-C-15 bond. Daphnioldhamine A (21) might be generated from the common intermediate, which involved an oxidative reaction to form the ether linkage between $\mathrm{C}-21$ and $\mathrm{C}-9$, and the $\mathrm{C}=\mathrm{O}$ group at $\mathrm{C}-11$. Daphnioldhamine $\mathrm{A}(\mathbf{2 1})$ is the first Daphniphyllum alkaloid with a transannular effect and was easily tautomerized under acidic or alkaline conditions. The structure of daphmacromine A (22) was confirmed by single-crystal X-ray diffraction.

\section{Bukittinggine}

Two new bukittinggine-type alkaloids, dapholdhamine A (32) [40] and angustimine (33) [41], were isolated (O Fig. 5). Dapholdhamine A (32) is closely related to bukittinggine. Angustimine (33) is an intramolecular salt featuring an unprecedented hexacyclic fused skeleton through the cleavage of a C-6-C-7 bond and the formation of a $\mathrm{C}-6-\mathrm{N}$ bond. The biosynthetic origin of angustimine (33) could be traced back to a bukittinggine-type alkaloid, caldaphnidine $\mathrm{P}$, which would give an intermediate after hydrolysis yielding angustimine (33) via a cascade of chemical reactions by involving the key steps of a C $-6-\mathrm{C}-7$ bond cleavage and a C-6-N bond formation.

\section{Daphnezomine A}

Daphnezomine A-type alkaloids possess a unique aza-adamantane core with an amino ketal bridge. Dapholdhamine B (34) was a zwitterion isolated from the leaves of D. oldhami [40] (๑ Fig. 5).

\section{Daphnezomine F}

Daphnezomine F-type alkaloids possess a characteristic 1-azabicyclo[5.2.2] undecane ring system. Two new daphnezomine Ftype alkaloids, daphnezomine U (35) [26] and daphlongeranine C (36) [36], were obtained ( Fig. 5). Daphlongeranine C (36) is the first daphnezomine F-type alkaloid obtained from the fruits of $D$. longeracemosum.

\section{Daphnezomine L}

Two new daphnezomine L-type alkaloids, daphnezomine L methyl ester (37) [25] and calycinumine B (38) [28], were reported ( Fig. 5). Daphnezomine L methyl ester (37) is structur- 


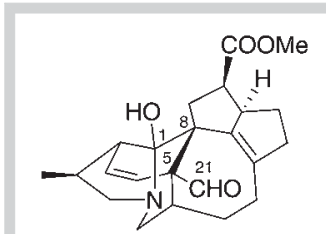

10

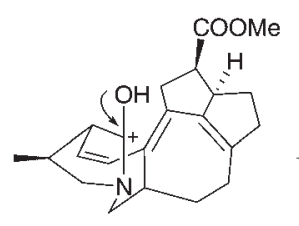

D

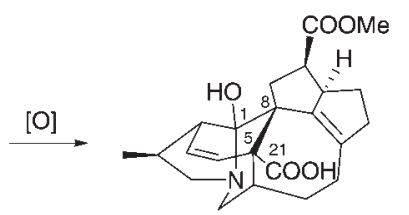

A

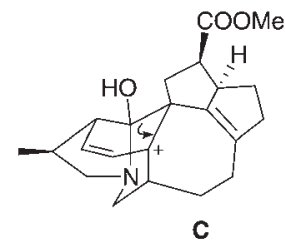

C

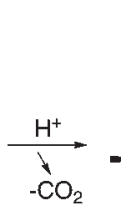

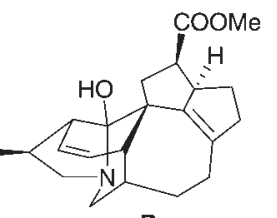

B

$\downarrow$

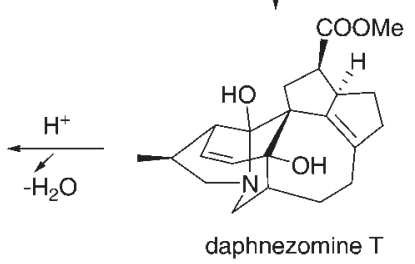

Fig. 3 Plausible biosynthetic pathway of daphnezomine T (9), daphhimalenine B (10), and daphhimalenine $A$ (53).

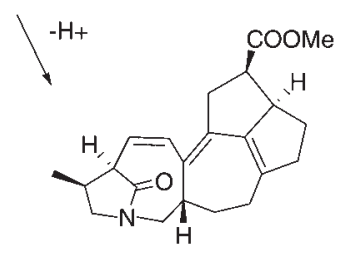

53

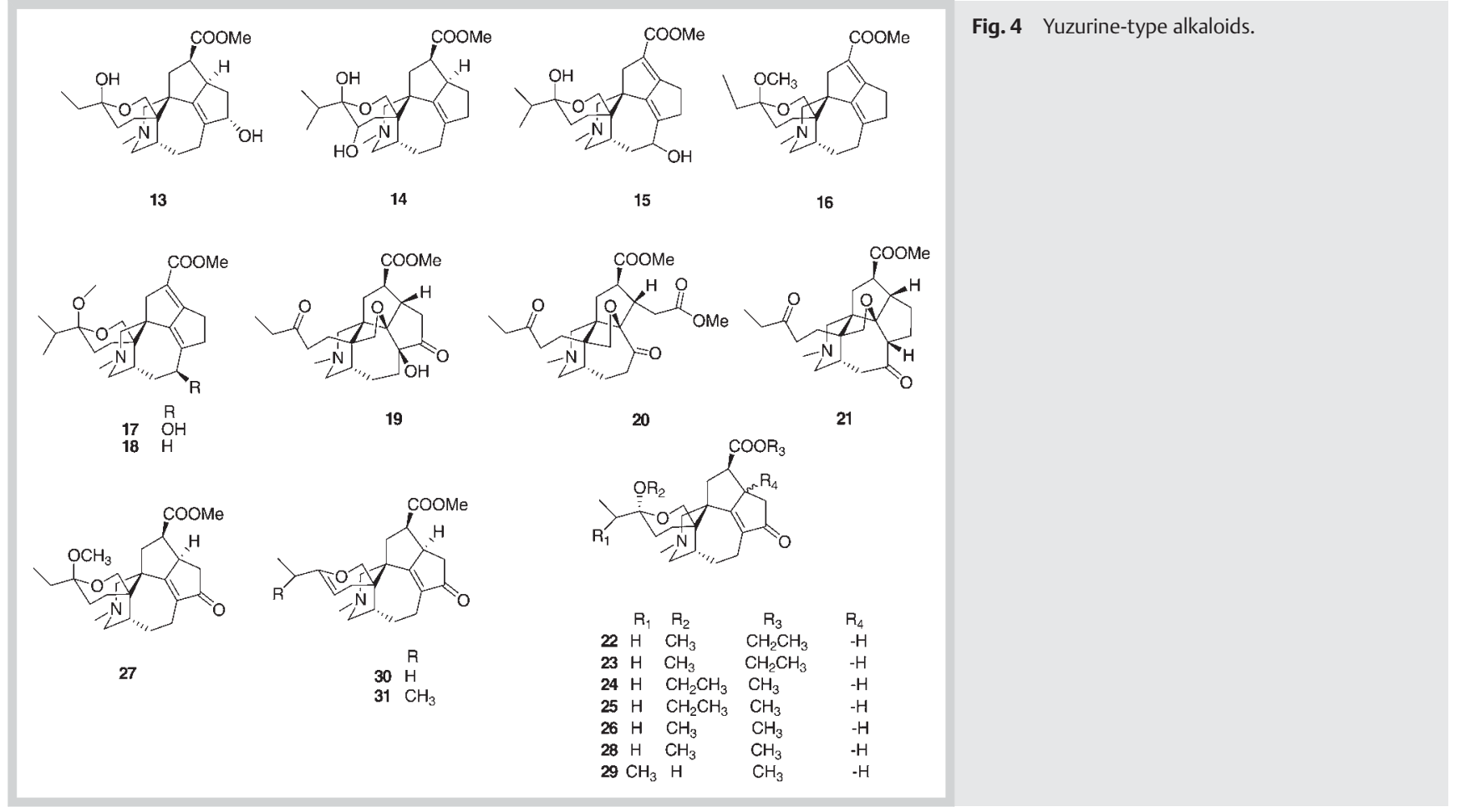

ally close to a hypothetical biogenetic intermediate between the secodaphniphylline and daphniphylline skeletons. Calycinumine B (38) features an unprecedented heteroatom-containing adamantane-like western hemisphere of the daphnezomine L-type alkaloid.

\section{Daphnicyclidin}

Daphnicyclidin-type alkaloids are a group of rare C-22 fused hexa- or pentacyclic nor-Daphniphyllum alkaloids. Five new daphnicyclidin-type alkaloids, dapholdhamines C (39) and D
(40) [40], caldaphnidine $H$ (41) [42], angustifolimine (42) [41], and paxiphylline $C(43)$ [43], were reported ( $\bullet$ Fig. 5). Angustifolimine (42) represents the second diamino Daphniphyllum alkaloid. Paxiphylline C (43) was the first Daphniphyllum alkaloid with an O-methylcarbonate group. Recently, the absolute configurations of two known compounds, macropodumines B and C, were determined by comparison between the experimental CD spectra and the TDDFT-calculated ones [44]. 

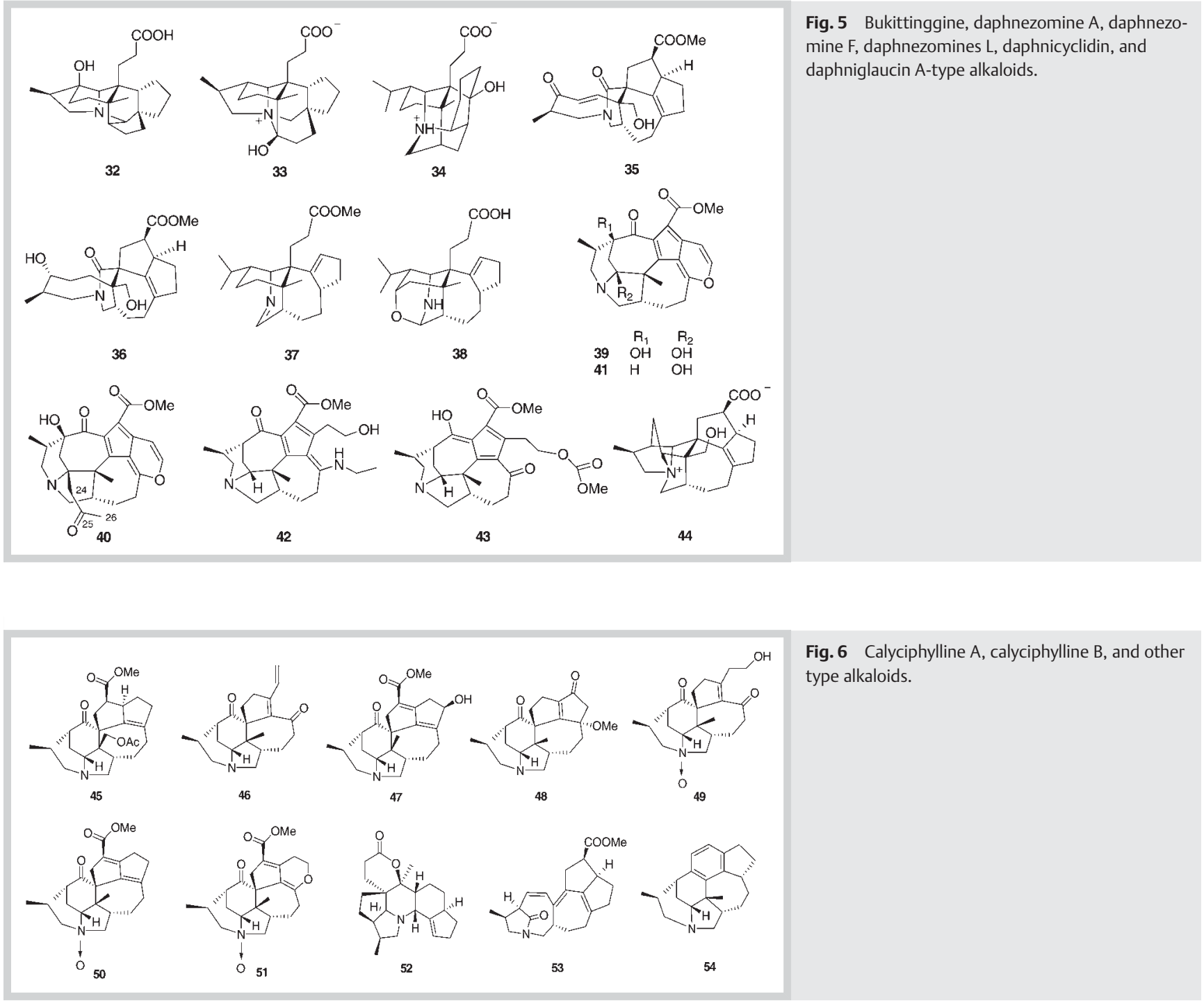

\section{Daphniglaucin A}

A new daphniglaucin A-type alkaloid, daphangustifoline A (44), was isolated from the whole plant of $D$. angustifolium [32] (๑ Fig. 5). Daphangustifoline A (44) was a zwitterion containing a 1-azoniatetracyclo[5.2.2.0 $\left.0^{1,6} \cdot 0^{4,9}\right]$ undecane ring system.

\section{Calyciphylline A}

Calyciphylline A-type alkaloids are a group of rare C-22 fused hexacyclic nor-Daphniphyllum alkaloids, biosynthesized by the fission of the $\mathrm{C}-1-\mathrm{N}$ bond of a yuzurimine-type alkaloid and the formation of a new bond between $\mathrm{C}-4$ and nitrogen. Calyciphylline A-type alkaloids possess a 6/5/5/7/5/6-membered ring system and an oxo group on C-1. Eight new calyciphylline A-type alkaloids, subdaphnidine A (45) [25], daphlongamines E-G (46-48) [45], daphhimalenine $\mathrm{D}$ (49) [33], and paxiphyllines $\mathrm{D}$ (50) and $\mathrm{E}$ (51) [43], were reported ( Fig. 6). Paxiphyllines D (50) and E (51) are the $\mathrm{N}$-oxide form of longistylumphylline $\mathrm{A}$ and daphnilongeranine $A$, respectively.

\section{Calyciphylline B}

Calyciphylline B-type alkaloids are a group of rare $C_{22}$ fused-pentacyclic yuzurimine-type nor-Daphniphyllum alkaloids. Most of them contained a six-member lactone ring. A new calyciphylline
B-type alkaloid, daphlongamine H (52), was reported (๑ Fig. 6) [45].

\section{Others}

In addition, two new structural types are reported. Daphhimalenine A (53), closely related to the yuzurimine-type alkaloids, was obtained from $D$. himalense [31]. Daphhimalenine A (53), with a rearranged $\mathrm{C}-21$ skeleton, contains a unique 1-azabicyclo[5.2.1] decane ring system with the cleavage of the $\mathrm{C}-1-\mathrm{C}-8$ bond (- Fig. 6). The absolute configuration of daphhimalenine A (53) was assigned by computational methods. Daphhimalenine A (53) was biogenetically related to daphhimalenine B (10). After dehydration, daphnezomine $\mathrm{T}$ (9) could further convert to the key carbonium intermediate $\mathrm{C}$, which finally underwent a carbocation rearrangement to afford a 1-azabicyclo[5.2.1]decane ring system in daphhimalenine A (53) (๑ Fig.3). Daphenylline (54), closely related to the calyciphylline A-type alkaloids, was obtained from D. longeracemosum ( Fig. 5) [46]. Daphenylline (54), possessing an unprecedented rearranged 22-nor-calyciphylline skeleton, has an expanded neohexatomic ring with C13 connected to $\mathrm{C}-1$ instead of $\mathrm{C}-8$ as usual. The absolute configuration of daphenylline (54) was elucidated on the basis of computational approaches. Daphenylline (54) might be biosyntheti- 


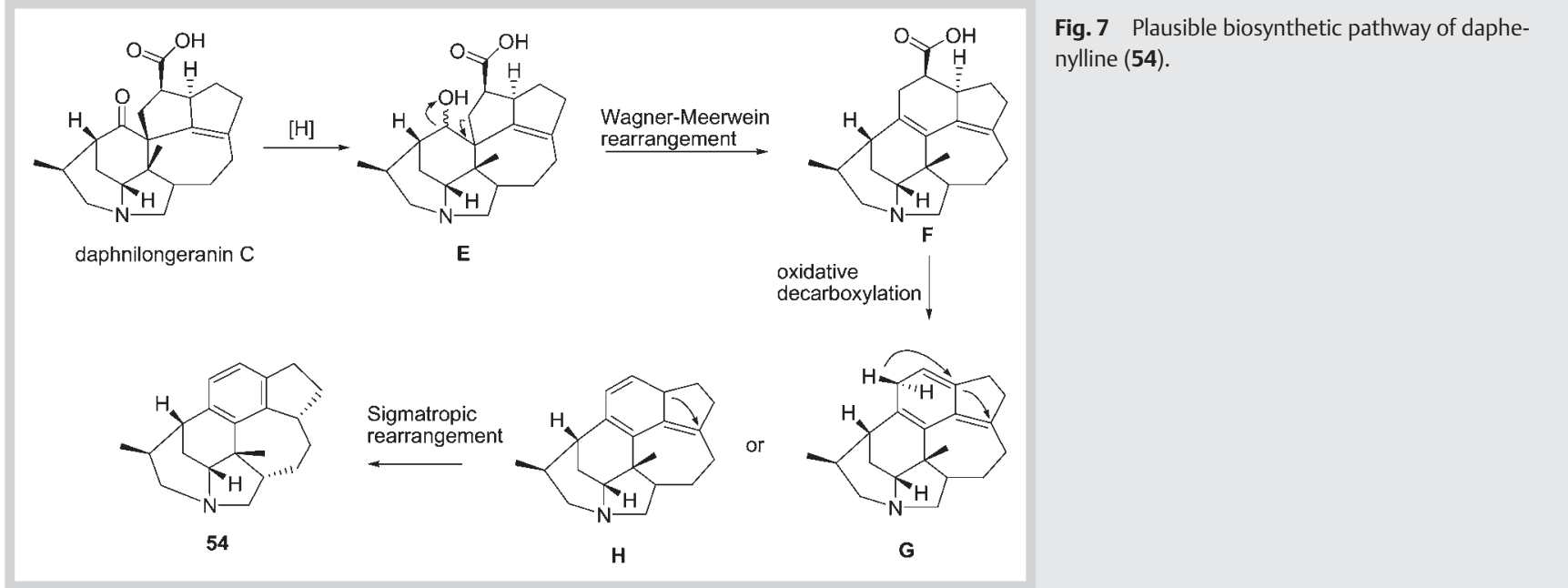

cally generated from daphnilongeranin $C$, which could be reduced and dehydrated to form a ring expanded intermediate $\mathbf{E}$ via the Wagner-Meerwein rearrangement. Then the intermediate $\mathbf{F}$ could be involved in the elimination of the carboxyl group at $\mathbf{C}-21$ by decarboxylase to generate intermediates $\mathbf{G}$ or $\mathbf{H}$ with a double bond between $\mathrm{C}-13$ and $\mathrm{C}-14$ or between $\mathrm{C}-14$ and $\mathrm{C}-$ 15 , followed by one or two steps of syn-[1,3] sigmatropic rearrangement to yield daphenylline (54) (๑ Fig. 7).

\section{Synthesis}

$\nabla$

The intriguing structures of Daphniphyllum alkaloids have been challenging organic chemists since the first Daphniphyllum alkaloid was unambiguously elucidated in the $1960 \mathrm{~s}$. The way in which the nitrogen atom(s) in Daphniphyllum alkaloids is (are) incorporated in nature can inspire the synthetic chemist to pursue a biomimetic approach [47]. Heathcock's biomimetic synthesis of the daphniphylline alkaloids is state-of-the-art work with a characteristic elegance and simplicity reminiscent of nature's approach to formidable structures [48]. Total synthesis has still been assuming a serious role in biology and medicine. A new synthetic strategy is increasingly focused on preparing complex molecules in the most efficient manner possible. In 2011, the first total synthesis of a daphmanidin A-type alkaloid, (+)-daphmanidin E, was reported by Weiss et al. [49]. Daphmanidin A-type alkaloids possess an unprecedented hexacyclic structure including a fused dihydropyrrole along with an embedded deca- or octahydrocyclopentazulene (oxide) around a central bicyclo[2.2.2]octane. The authors used an elegant strategy involving rapid access to an enantiomerically pure bicyclo-[2.2.2]octadione and elaboration around its periphery by implementing two Claisen rearrangements, a diastereoselective hydroboration and a cobalt-catalyzed alkyl-Heck cyclization ( $\bullet$ Fig. 8).

For a successful total synthesis, a robust and practical route for the expedient construction of common cores in highly complex molecules is a prerequisite. Recently, the rapid assembly of the structural motif in Daphniphyllum alkaloids was fruitfully completed. In 2012, several strategies for constructions of different moieties present in the calyciphylline A-type alkaloid are reported. Darses et al. developed a synthetic strategy for the construction of the [7-5-5] tricyclic core using a key intramolecular Pauson-Khand reaction (IPKR) [50]. Subsequently, the synthesis of daphnilongeranin B and daphniyunnine D would be completed via late stage, base-mediated, double-bond migration and a regio- and stereoselective radical allylic oxygenation based on a DEF tricyclic ring system ( $\odot$ Fig. 9). In another study, an efficient and scalable synthesis of a bowl-shaped [6-6-5] skeleton was developed from a readily available carvone derivative through a seven-step sequence involving an aza-Michael addition and Pdcatalyzed enolate R-vinylation [51]. Li and coworkers constructed a [6-6-6-5] bridged ABCE tetracyclic skeleton via a stereoselective intramolecular 2-azaallyl anion cycloaddition in only 8 steps [52]. Additionally, Yang et al. completed the construction of 6substituted spiro[4.5]decane, an important structural motif, using the tandem semipinacol-type 1,2-carbon migration/aldol reaction [53].

Cascade reactions are a useful method for the construction of polycyclic skeletons, which are important cores for biological activities [54]. Coldham et al. reported the first synthesis of the core ring system of the yuzurimine-type alkaloids by a cascade of condensation, cyclization, then intramolecular dipolar cycloaddition reactions [55]. In another study, a similar approach was successfully extended to bridged tricyclic compounds, yuzurimine $\mathrm{B}$, daphnilactone $\mathrm{B}$, and bukittinggine [56].

In 2009, two reports about asymmetric synthesis of cores common in daphnicyclidin-A-type alkaloids were published. Ikeda and coworkers first described an enantiocontrolled access to the tricyclic intermediate corresponding to the BCD portion [6-5-7] of daphnicyclidin A through the highly diastereoselective conjugate addition of nitromethane, an Ireland-Claisen rearrangement, and a tandem acyliminium/Mannich-type reaction [57]. In another report, the aza-Cope-Mannich reaction and ring-closing metathesis were used as key steps in the assembly of intermediates containing rings A-D [58].

In addition, a new type of template-assisted cyclization for the formation of crownophane bearing the azaheterocyclic fragment with the same core structure of 2-azabicyclo[2.2.2] oct-2-ene was described [59]. An asymmetric synthesis of the ABCD ring system of daphnilactone B is also reported [60]. A tricyclic substructure of the tetracyclic nitrogen core of the daphniglaucins was synthesized by an oxidative activation of the allyl side chain of a bicyclo [1.1.0]butylmethylamine, a spontaneous intramolecular formal Alder-ene reaction, and a selective cyclization of a triol intermediate [61]. 


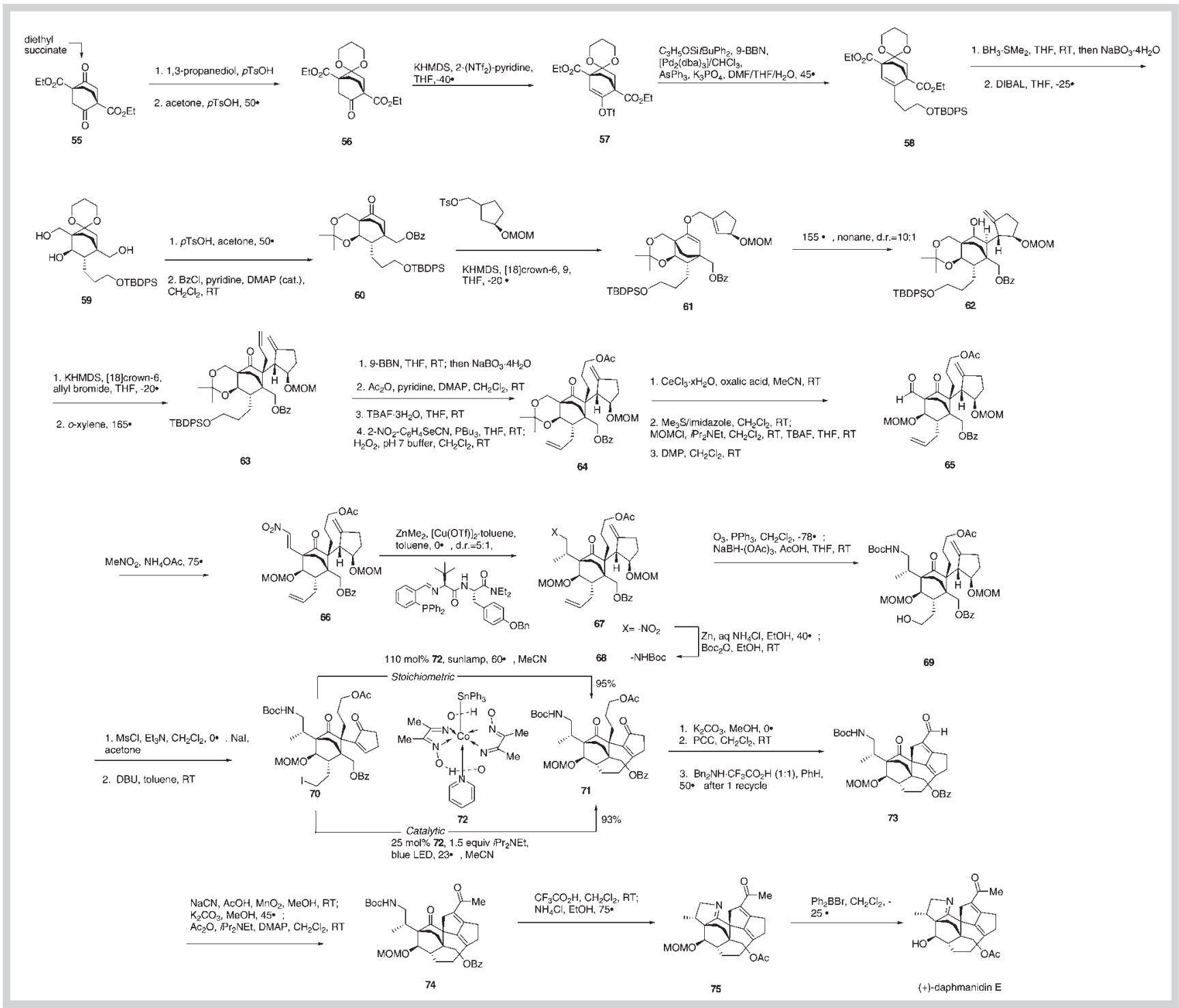

Fig. 8 Synthesis of (+)-daphmanidin E.

\section{Bioactivities}

$\nabla$

The cytotoxicity of some Daphniphyllum alkaloids against different human tumor cell lines was evaluated ( Table 2). Daphangustifoline B (12) showed weak inhibition of tumor growth against the HL-60 (human promyelocytic leukemia), MCF-7 (human breast adenocarcinoma), and A549 (human lung adenocarcinoma) cell lines [32]. Daphnilongeridine exhibited cytotoxicity against several tumor cell lines with $\mathrm{IC}_{50}$ values in the range of 2.4-9.7 $\mu \mathrm{M}$ and against the HMEC (human microvascular endothelial) cell line with an $\mathrm{IC}_{50}$ of $2.7 \mu \mathrm{M}$ [25]. In addition, daphmacromines A-J (23-32) in vitro displayed pesticide activities against brine shrimp (Artemia salina) at $100 \mathrm{mg} / \mathrm{L}$, and the corrected lethality ranged from $40.98 \%$ to $70.90 \%$. Two known alkaloids, deoxyyuzurimine and yuzurimine $\mathrm{C}$, showed higher corrected lethality values of $81.81 \%$ and $80.56 \%$, respectively [39]. It is likely that the Daphniphyllum alkaloids play an important role in the protection of the plants which produce them against attacking insects [29]. Daphtedinine C exhibited the most potent insecticidal effect against Plutella xylostella and a moderate effect against
Heliothis virescens, while deoxyyuzurimine and daphnicyclidin D showed weak insecticidal effects against Aphis gossypii. Recently, Zhang et al. found that deoxycalyciphylline B was mainly responsible for the hepatoxicity of D. calycinum [62].

\section{Conclusions}

$\nabla$

So far, more than 250 alkaloids have been reported from 15 species of the Daphniphyllum genus. It is highly likely that further phytochemical investigations on the other species will result in many more isolations of Daphniphyllum alkaloids with structural variations. Total syntheses of Daphniphyllum alkaloids are now underway, and the biosynthesis of Daphniphyllum alkaloids requires thorough studies to elucidate the intermediates and the relevant enzymes. The biological activities of Daphniphyllum alkaloids should be extensively investigated. In addition, plants of the genus Daphniphyllum produce structurally diverse and complex alkaloids, which should play an important role for the plant itself from the evolutionary perspective. Biological/ecological 


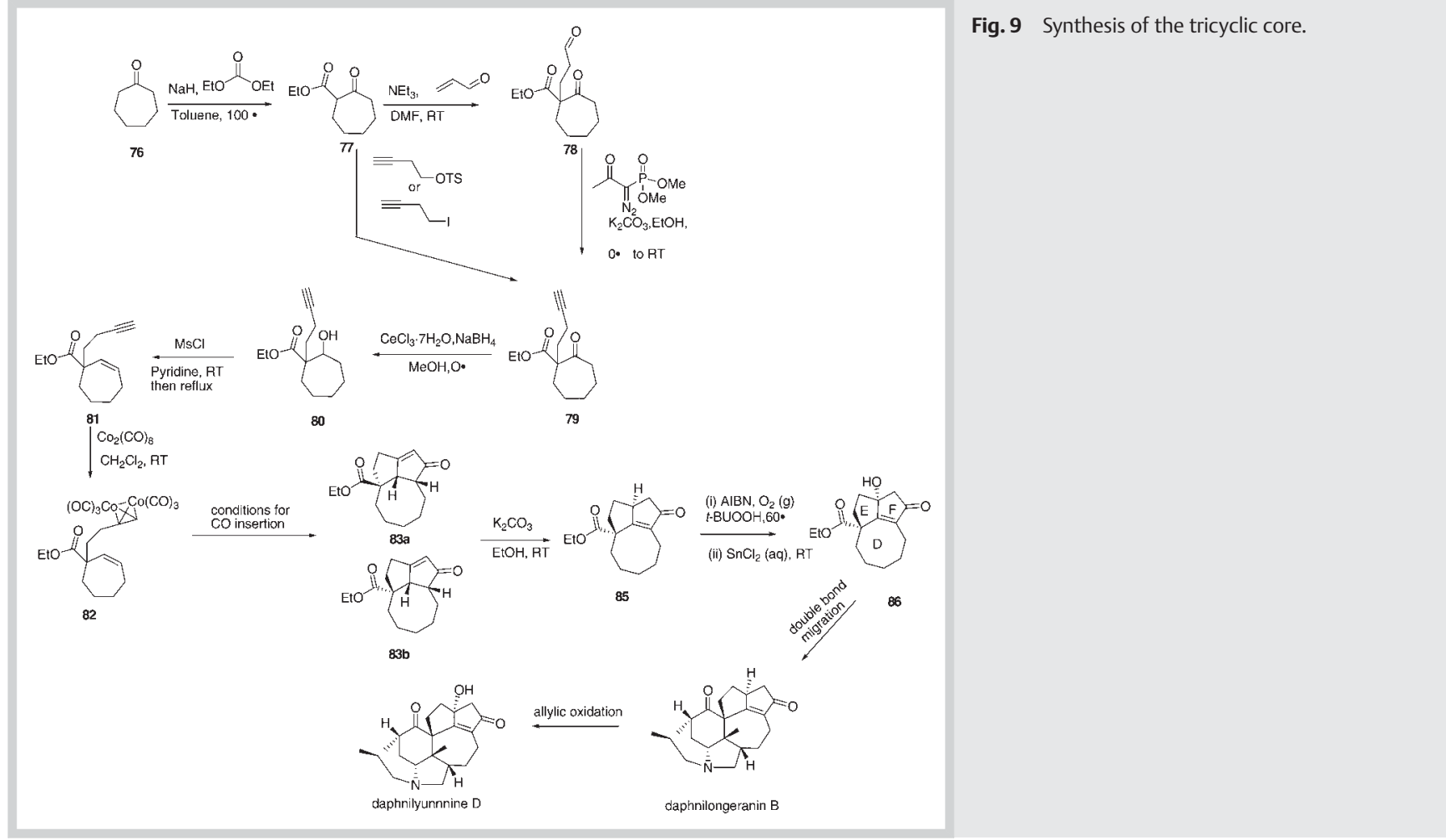

Table 2 Bioactivity of Daphniphyllum alkaloids obtained recently.

\begin{tabular}{|c|c|c|c|c|c|c|c|}
\hline \multirow[t]{2}{*}{ Compounds } & \multicolumn{6}{|c|}{ Cytotoxicity $\left(\mathrm{IC}_{50} / \mu \mathrm{M}\right)$} & \multirow[t]{2}{*}{ References } \\
\hline & HL-60 & MCF-7 & A549 & P-388 & BEL-7402 & HMEC & \\
\hline Daphangustifoline B & weak & weak & weak & - & - & - & [32] \\
\hline Daphnilongeridine & 9.5 & - & - & 2.4 & 9.7 & 2.7 & [25] \\
\hline
\end{tabular}

role of these alkaloids in the life cycle of the plant should also be paid much more attention.

\section{Acknowledgements}

Financial support from the National Natural Science Foundation of China (No.81102770), Chinese Traditional Medicine Researches of Special Projects (No.200707007), the technological large platform for comprehensive research and development of new drugs in the Twelfth Five-Year "Significant New Drugs Created" Science and Technology Major Projects (No. 2012ZX09301-002-001-026), and the chemical composition of the digital library of traditional Chinese medicine for drug discovery in the Twelfth Five-Year "Significant New Drugs Created" (No. 2011ZX09307-002-01) is gratefully acknowledged.

\section{Conflict of Interest}

$\nabla$

The authors have no conflicts of interest.

\section{References}

1 Kubitzki K. Daphniphyllaceae flowering plants eudicots. Berlin, Heidelberg: Springer; 2007: 127-128

2 Yagi S. Daphniphyllum alkaloid. Kyoto Igaku Zasshi 1909; 6: 208-222
3 Fang SD, Zhou W, Chen Y, Chu JH. Alkaloids of the poisonous plant NiuEr-Fon Daphniphyllum calycinum Benth. Acta Chim Sin 1964; 30: 270274

4 Arthur HR, Chan RPK, Loo SN. Alkaloids of Daphniphyllum calycinum and D. glaucescens of Hong Kong. Phytochemistry 1965; 4: 627-629

5 Sakabe N, Irikawa H, Sakurai H, Hirata Y. Isolation of 3 new alkaloids from Daphniphyllum macropodum Miquel. Tetrahedron Lett 1966; 7: 963-964

6 Sakabe N, Hirata Y. X-ray structure determination of a new type alkaloid, daphniphylline hydrobromide. Tetrahedron Lett 1966; 7: 965968

7 Sakurai H, Sakabe N, Hirata Y. X-ray structure determination of yuzurimine hydrobromide. Tetrahedron Lett 1966; 7: 6309-6314

8 Heathcock CH, Davidsen SK, Mills S, Sanner MA. Total synthesis of ( \pm )-methyl homodaphniphyllate. J Am Chem Soc 1986; 108: 56505651

9 Ruggeri RB, McClure KF, Heathcock CH. Daphniphyllum alkaloids. Part 5. Total synthesis of $( \pm)$-daphnilactone A: a novel fragmentation reaction. J Am Chem Soc 1989; 111: 1530-1531

10 Stafford JA, Heathcock CH. Daphniphyllum alkaloids. Part 8. Asymmetric total synthesis of (-)-secodaphniphylline. J Org Chem 1990; 55: 5433-5434

11 Heathcock CH, Davidsen SK, Mills SG, Sanner MA. Daphniphyllum alkaloids. 10. Classical total synthesis of methyl homodaphniphyllate. J Org Chem 1992; 57: 2531-2544

12 Heathcock $\mathrm{CH}$. Nature knows best: an amazing reaction cascade is uncovered by design and discovery. Proc Natl Acad Sci USA 1996; 93: 14 323-14 327

13 Heathcock CH, Hansen MM, Ruggeri RB, Kath JC. Daphniphyllum alkaloids. 11. Biomimetic total synthesis of methyl homosecodaphniphyl- 
late. Development of the tetracylization reaction. J Org Chem 1992; 57 : 2544-2553

14 Heathcock CH, Joe D. Daphniphyllum alkaloids. 17. A possibly biomimetic transformation of the secodaphnane to the daphnane skeleton. J Org Chem 1995; 60: 1131-1142

15 Heathcock CH, Piettre S, Ruggeri RB, Ragan JA, Kath JC. Daphniphyllum alkaloids. 12. A proposed biosynthesis of the pentacyclic skeleton. proto-Daphniphylline. J Org Chem 1992; 57: 2554-2566

16 Heathcock $\mathrm{CH}$, Piettre S, Kath J. Mechanic investigations of a biomimetic polycyclization process that leads to the Daphniphyllum alkaloids. Pure Appl Chem 1990; 62: 1911-1920

17 Ruggeri RB, Heathcock CH. A proposal for biosynthesis of the Daphniphyllum alkaloids. Pure Appl Chem 1989; 61: 289-292

18 Piettre S, Heathcock $\mathrm{CH}$. Total synthesis of proto-daphniphylline. Science 1990; 248: 1532-1534

19 Yamamura S, Hirata Y. The Daphniphyllum alkaloids. In: Manske RHF, editor. The alkaloids, Volume 12. New York: Academic Press; 1975: $41-81$

20 Yamamura S. Daphniphyllum alkaloids. In: Brossi A, editor. The alkaloids, Volume 29. New York: Academic Press; 1986: 265-286

21 Kobayashi J, Morita H. Daphniphyllum alkaloids. In: Cordell GA, editor. The alkaloids, Volume 60. New York: Academic Press; 2003: 165-205

22 Li ZY, Guo YW. Progress in the study of Daphniphyllum alkaloids. Chin J Org Chem 2007; 27: 565-575

23 Dong M, Zhang ML, Shi QW, Gu YC, Kiyota H. The Daphniphyllum alkaloids. Curr Org Chem 2009; 13: 646-682

24 Kobayashi JI, Kubota T. The Daphniphyllum alkaloids. Nat Prod Rep 2009; 26: 936-962

25 Zhang CR, Liu HB, Feng T, Zhu JY, Geng MY, Yue JM. Alkaloids from the leaves of Daphniphyllum subverticillatum. J Nat Prod 2009; 72: 16691672

26 Kubota T, Suzuki T, Ishiuchi K, Kuhara T, Kobayashi J. Daphnezomines TV, alkaloids from Daphniphyllum humile. Chem Pharm Bull 2009; 57: 504-507

27 Li ZY, Peng SY, Fang L, Yang YM, Guo YW. Two new Daphniphyllum alkaloids from the stems and leaves of Daphniphyllum calycinum. Chem Biodivers 2009; 6: 105-110

28 Zhang CR, Liu HB, Dong SH, Zhu JY, Wu Y, Yue JM. Calycinumines A and B, two novel alkaloids from Daphniphyllum calycinum. Org Lett 2009; 11: 4692-4695

29 Li ZY, Gu YC, Irwin D, Sheridan J, Clough J, Chen P, Peng SY, Yang YM, Guo YW. Further Daphniphyllum alkaloids with insecticidal activity from the bark of Daphniphyllum macropodum MIQ. Chem Biodivers 2009; 6: $1744-1750$

30 Li ZY, Xu HG, Zhao ZZ, Guo YW. Two new Daphniphyllum alkaloids from Daphniphyllum macropodum Miq. J Asian Nat Prod Res 2009; 11: 153158

31 Zhang Y, Di YT, Zhang Q Mu SZ, Tan CJ, Fang X, He HP, Li SL, Hao XJ. Daphhimalenine A, a new alkaloid with an unprecedented skeleton, from Daphniphyllum himalense. Org Lett 2009; 11: 5414-5417

32 He T, Zhou Y, Wang YH, Mu SZ, Hao XJ. Two new akaloids from Daphniphyllum angustifolium Hutch. Helv Chim Acta 2011; 94: 1019-1023

33 Zhang Y, He HP, Guo LL, Li SF, Di YT, Hao XJ. Daphhimalenines C and D. New alkaloids from Daphniphyllum himalense. Z Naturforsch 2012; 67: 407-410

34 Li CS, Di YT, Guo J, Zhang Q Fang X, Hao XJ. Daphlongamines I and J. New yuzurine-type alkaloids from Daphniphyllum longeracemosum. Z Naturforsch A 2010; 65: 1406-1408

35 Yang TQ Di YT, He HP, Hao XJ. A new alkaloid from the fruits of Daphniphyllum longeracemosum (Daphniphyllaceae). Yunnan Zhiwu Yanjiu 2010; 32: 561-563

36 Yang TQ Di YT, He HP, Zhang Q Zhang Y, Hao XJ. Further alkaloids from the fruits of Daphniphyllum longeracemosum. Helv Chim Acta 2011; 94 : 397-403

37 Zhang Y, Di YT, He HP, Li SF, Lu Y, Gong NB, Hao XJ. Daphmalenines A and B: Two new alkaloids with unusual skeletons from Daphniphyllum himalense. Eur J Org Chem 2011; 2011: 4103-4107

38 Tan CJ, Wang YH, Di YT, He HP, Mu SZ, Li SF, Zhang Y, Hao XJ. Daphnioldhamine A, a novel alkaloid from Daphniphyllum oldhami. Tetrahedron Lett 2012; 53: 2588-2591
39 Cao MM, Zhang Y, He HP, Li SF, Huang SD, Chen DZ, Tang GH, Li SL, Di YT, Hao XJ. Daphmacromines A-J, alkaloids from Daphniphyllum macropodum. J Nat Prod 2012; 75: 1076-1082

40 Zhang Y, Di YT, Mu SZ, Li CS, Zhang Q Tan CJ, Zhang Z, Fang X, Hao XJ. Dapholdhamines A-D, alkaloids from Daphniphyllum oldhami. J Nat Prod 2009; 72: 1325-1327

41 Zhang CR, Fan CQ Dong SH, Liu HB, Zhou WB, Wu Y, Yue JM. Angustimine and Angustifolimine: two new alkaloids from Daphniphyllum angustifolium. Org Lett 2011; 13: 2440-2443

42 Zhan ZJ, Rao GW, Hou XR, Li CP, Shan WG. Alkaloids from the leaves and stems of Daphniphyllum calycinum. Helv Chim Acta 2009; 92: 15621567

43 Zhang Y, Di YT, Liu HY, Li CS, Tan CJ, Zhang Q Fang X, Li SL, Hao XJ. Three new alkaloids, paxiphyllines C-E, from Daphniphyllum paxianum. Helv Chim Acta 2008; 91: 2153-2158

44 Guo YW, Kurtán T, Krohn K, Pescitelli G, Zhang W. Assignment of the absolute configuration of zwitterionic and neutral macropodumines by means of TDDFT CD calculations. Chirality 2009; 21: 561-568

$45 \mathrm{Li}$ CS, Di YT, Zhang Q Zhang Y, Tan CJ, Hao XJ. Alkaloids from the leaves of Daphniphyllum longeracemosum Rosenth. Helv Chim Acta 2009; 92: 653-659

46 Zhang $Q$ Di YT, Li CS, Fang X, Tan CJ, Zhang Z, Zhang Y, He HP, Li SL, Hao $X J$. Daphenylline, a new alkaloid with an unusual skeleton, from Daphniphyllum longeracemosum. Org Lett 2009; 11: 2357-2359

47 Cherney EC, Baran PS. Terpenoid-alkaloids: Their biosynthetic twist of fate and total synthesis. Isr J Chem 2011; 51: 391-405

$48 \mathrm{Kim} \mathrm{J}$, Movassaghi M. Biogenetically inspired syntheses of alkaloid natural products. Chem Soc Rev 2009; 38: 3035-3050

49 Weiss ME, Carreira EM. Total synthesis of (+)-daphmanidin E. Angew Chem Int Ed Engl 2011; 50: 11 501-11 505

50 Darses B, Michaelides IN, Sladojevich F, Ward JW, Rzepa PR, Dixon DJ. Expedient construction of the [7-5-5] all-carbon tricyclic core of the Daphniphyllum alkaloids daphnilongeranin B and daphniyunnine D. Org Lett 2012; 14: 1684-1687

51 Yao Y, Liang G. Rapid construction of the ABC ring system in the Daphniphyllum alkaloid daphniyunnine $C$. Org Lett 2012; 14: 5499-5501

52 Li HL, Zheng JY, Xu SY, Ma DH, Zhao CG, Fang BW, Xie XG, She XG. Rapid construction of the [6-6-6-5] tetracyclic skeleton of the Daphniphyllum alkaloid daphenylline. Chem Asian J 2012; 7: 2519-2522

53 Yang $M$, Wang L, He ZH, Wang SH, Zhang SY, Tu YQ Zhang FM. Tandem semipinacol-type 1,2-carbon migration/aldol reaction toward the construction of [5-6-7] all-carbon tricyclic core of calyciphylline A-type alkaloids. Org Lett 2012; 14: 5114-5117

54 Ihara M. Cascade reactions for syntheses of heterocycles. Arkivoc 2006 vii: $416-438$

55 Coldham I, Watson L, Adams H, Martin NG. Synthesis of the core ring system of the yuzurimine-type Daphniphyllum alkaloids by cascade condensation, cyclization, cycloaddition chemistry. J Org Chem 2011; 76: $2360-2366$

56 Coldham I, Burrell AJM, Guerrand HDS, Oram N. Cascade cyclization, dipolar cycloaddition to bridged tricyclic amines related to the Daphniphyllum alkaloids. Org Lett 2011; 13: 1267-1269

57 Ikeda S, Shibuya M, Kanoh N, Iwabuchi Y. Synthetic studies on daphnicyclidin A: enantiocontrolled construction of the BCD ring system. Org Lett 2009; 11: 1833-1836

58 Dunn TB, Ellis JM, Kofink CC, Manning JR, Overman LE. Asymmetric construction of rings A-D of daphnicyclidin-type alkaloids. Org Lett 2009; 11: 5658-5661

59 Ovchinnikova IG, Fedorova OV, Matochkina EG, Kodess MI, Tumashov AA, Slepukhin PA, Rusinov GL, Charushin VN. The first example of cascade synthesis of alkaloid-like subunit incorporated into crown ethers. Macroheterocycles 2012; 3: 108-113

60 Denmark SE, Baiazitov RY, Nguyen ST. Tandem double intramolecular $[4+2] /[3+2]$ cycloadditions of nitroalkenes: construction of the pentacyclic core structure of daphnilactone B. Tetrahedron 2009; 65: 6535-6548

61 Ueda M, Walczak MAA, Wipf P. Formal Alder-ene reaction of a bicyclo [1.1.0]butane in the synthesis of the tricyclic quaternary ammonium core of daphniglaucins. Tetrahedron Lett 2008; 49: 5986-5989

62 Zhang X, Zhang J, Tan Y, Liu Q Liu M. Deoxycalyciphylline B, a hepatotoxic alkaloid from Daphniphyllum calycinum. Molecules 2012; 17 : 9641-9651 